\title{
FAKTOR-FAKTOR YANG BERHUBUNGAN DENGAN PEMANFAATAN LAYANAN MAWAS OLEH KARYAWATI DINAS KESEHATAN KABUPATEN BADUNG
}

\author{
N. P. O. M. Prasari*, N. M. S. Nopiyani \\ Program Studi Kesehatan Masyarakat Fakultas Kedokteran Universitas Udayana \\ *email: manikprasari92@yahoo.co.id
}

\begin{abstract}
ABSTRAK
Layanan Kesehatan Perempuan (MAWAS) merupakan layanan deteksi dini kanker payudara di Kabupaten Badung sejak tahun 2015. Pemanfaatan Layanan tersebut oleh karyawati Dinas Kesehatan Kabupaten Badung masih rendah. Tujuan penelitian ini untuk mengetahui hubungan karakteristik sosio demografi, pengetahuan tentang layanan dan persepsi risiko kanker payudara dengan pemanfaatan Layanan Kesehatan Perempuan (MAWAS) oleh karyawati Dinas Kesehatan Kabupaten Badung. Rancangan penelitian ini adalah cross sectional analitik. Responden penelitian ini terdiri dari seluruh karyawati Dinas Kesehatan Kabupaten Badung yang berjumlah 111 orang yang dipilih melalui total sampling. Metode pengumpulan data dengan menggunakan survey kuesioner yang diisi sendiri oleh responden. Analisis data dilakukan dengan menggunakan uji chi square. Hasil penelitian menunjukkan sebanyak 58,56\% responden pernah memanfaatkan layanan MAWAS. Sebagian besar responden memiliki pengetahuan kurang tentang layanan $(54,05 \%)$ dan sebagian besar responden memiliki persepsi kurang berisiko terhadap kanker payudara (71,17\%). Terdapat hubungan antara karakteristik umur $(\mathrm{p}=$ $0,034)$, status kepegawaian $(\mathrm{p}=0,005)$ dan pengetahuan tentang layanan $(\mathrm{p}<0,001)$ dengan pemanfaatan layanan. Peningkatan sosialisasi tentang Layanan Kesehatan Perempuan (MAWAS) berupa media cetak seperti brosur perlu dilakukan kepada karyawati untuk meningkatkan pemanfaatan layanan.
\end{abstract}

Kata Kunci : Pemanfaatan Layanan, Deteksi Dini Kanker Payudara, Pengetahuan, Determinan

ABSTRACT

Women's Health Services is an early breast cancer detection service in Badung since 2015. The service utilization by women employees of Badung Health Departement is still low. The aim of this study was to associated between socio demographic characteristics, knowledge about services and risk perception of the breast cancer with services utilization among women employees of Badung Health Departement. This was cross sectional analytic study. The subjects of this study were of women employees of Badung Health Departement selected by totally sampling. The data was collected through self administrate questionare survey. Chi square test was use in data analysis. The study showed that $58.56 \%$ respondents used the service. Most of respondents had less knowledge about services (54.05\%) and most of respondents had less perception risk of the breast cancer $(71.17 \%)$. There is an association between age characteristics, staffing status, and knowledge about the service with service utilization. Effort to promote the availability of Women's Health Services in the form of printed material such as brochures should be conducted to improved service utilization.

Keywords : Utilization of Services, Early Detection of Breast Cancer, Determinant

\section{PENDAHULUAN}

Kanker payudara adalah kanker yang paling umum didiagnosis pada wanita, mencapai 24,2\% atau sekitar 1 dari 4 dari semua kasus kanker baru yang didiagnosis pada wanita di seluruh dunia. GLOBOCAN The International Agency for Research on Cancer (IARC) menyebutkan tingkat kejadian kanker payudara jauh melebihi kanker lainnya seperti kanker kolon dan rektum, kanker paru-paru serta kanker serviks di negara maju dan berkembang yang berdampak pada 2,1 juta wanita setiap tahun. Kanker payudara juga merupakan penyebab utama kematian akibat kanker pada wanita dimana pada tahun 2018, diperkirakan 627.000 wanita 
meninggal karena kanker payudara yaitu sekitar $15 \%$ dari semua kematian akibat kanker pada wanita. (WHO, 2018a) Dimana angka insiden kanker payudara di Indonesia sebesar 34,00 - 43,66 per 100.000 penduduk dengan angka kematian sebesar 16,7 - 20,00 per 100.000 penduduk. (WHO, 2018b). Saat ini diperkirakan jumlah kasus kanker payudara di Provinsi Bali mencapai 1,99\% dari total kasus kanker payudara di Indonesia. (Kementerian Kesehatan RI, 2015)

Berbagai upaya telah dilakukan untuk mencegah penyakit kanker payudara, diantaranya melalui program pengendalian kanker yang meliputi upaya promotif dan preventif dengan meningkatkan pengetahuan masyarakat akan kanker melalui kegiatan pemberdayaan masyarakat berupa deteksi dini kanker salah satunya dilakukan pemeriksaan payudara klinis (SADANIS) yaitu pemeriksaan oleh petugas kesehatan. (Kementerian Kesehatan RI, 2015). Kabupaten Badung merupakan salah satu kabupaten di Bali yang turut gencar melakukan upaya pencegahan penyakit kanker payudara melalui sebuah program yang diberinama Layanan Kesehatan Perempuan (MAWAS) yang sudah berjalan selama kurang lebih 4 tahun. Layanan tersebut tidak hanya dapat dimanfaatkan oleh masyarakat di Kabupaten Badung saja, namun juga oleh karyawati di lingkungan Pemerintah Kabupaten Badung termasuk salah satunya adalah karyawati Dinas Kesehatan Kabupaten Badung. Namun sampai saat ini pemanfaatannya oleh karyawati Dinas
Kesehatan Kabupaten Badung masih belum optimal.

Penelitian yang pernah dilakukan kepada tenaga kesehatan diperoleh hasil bahwa sebagian besar perawat melakukan pemeriksaan payudara sendiri dalam 12 bulan terakhir (85\%), tetapi hanya $17,7 \%$ yang melakukannya setiap bulan. (Alkhasawneh, Akhu-Zaheya and Suleiman, 2009) Penelitian lain yang pernah dilakukan Pratama (2017) pada populasi Wanita Usia Subur (WUS) di Kecamatan Abiansemal, Kabupaten Badung didapatkan hasil bahwa umur, tingkat pengetahuan, praktek melakukan pemeriksaan payudara sendiri, dan persepsi ancaman untuk menderita kanker payudara berhubungan dengan kesediaan melakukan skrining kanker payudara. Penelitian ini bertujuan untuk mengetahui hubungan karakteristik sosio demografi , pengetahuan tentang layanan dan persepsi risiko kanker payudara dengan pemanfaatan Layanan Kesehatan Perempuan (MAWAS) oleh karyawati Dinas Kesehatan Kabupaten Badung.

\section{METODE}

Rancangan penelitian yang digunakan adalah cross sectional analitik. Responden pada penelitian ini terdiri dari seluruh karyawati Dinas Kesehatan Kabupaten Badung yang berjumlah 111 orang yang dipilih melalui total sampling. Metode pengumpulan data dilakukan dengan menggunakan survey kuesioner yang diisi sendiri oleh responden yang didalamnya mencakup pertanyaan karakteristik sosio-demografi, perngetahuan tentang layanan, persepsi risiko kanker payudara, dan pemanfaatan 
Layanan MAWAS. Pertanyaan karakteristik sosio-demografi terdiri dari umur, status perkawinan, status kepegawaian, lama bekerja, pendidikan terakhir, riwayat kanker payudara Pernyataan pengetahuan tentang layanan berisi 15 pernyataan mengenai pemanfaatan layanan dan prosedur pemeriksaan. Setiap pernyataan diberikan kriteria benar, salah dan tidak tahu. Serta dilakukan pengkategorian pengetahuan yaitu baik dan kurang. Setelah dilakukan penjumlahan skor terhadap semua pernyataan mengenai pengetahuan tentang layanan, maka akan dibandingkan dengan nilai median. Jika skor > median maka akan dikategorikan pengetahuan baik. Apabila skor $\leq$ median maka akan dikategorikan pengetahuan kurang. Pertanyaan mengenai persepsi risiko kanker payudara diberikan 1 pertanyaan dengan kriteria jawaban kurang berisiko, cukup berisiko dan sangat berisiko. Analisis data dilakukan dengan menggunakan uji chi square. Penelitian ini juga telah dinyatakan laik etik oleh Komisi Etik Fakultas Kedokteran Universitas Udayana dengan Nomor 1367/UN14.2.2.VII.14/LP/ Tanggal 10 Mei 2019.

\section{HASIL}

Tabel 1 menunjukkan berdasarkan karakteristik kelompok umur, dari 111 karyawati penelitian proporsi tertinggi berada pada kelompok umur dewasa penuh (26-65 tahun) yaitu sebanyak 88 (79,28\%). Rata-rata umur karyawati adalah 34,5 tahun, umur terendah karyawati adalah 22 tahun sedangkan umur tertinggi adalah 57 tahun. Berdasarkan karakteristik status perkawinan, proporsi karyawati tertinggi yakni karyawati dengan status kawin yakni 77 responden (69,37\%). Pada karakteristik status kepegawaian, karyawati dengan proporsi terbanyak merupakan tenaga kegiatan (kontrak) yaitu sebanyak 58,86\%. Pada karakeristik lama bekerja, hampir sebagian besar karyawati bekerja > 1 tahun yakni sebanyak 94,59\%. Rata-rata lama bekerja karyawati adalah 6 tahun, dengan lama bekerja terendah karyawati adalah selama 1 tahun sedangkan yang tertinggi adalah selama 32 tahun. Berdasarkan karakteristik pendidikan terakhir, sebanyak 59,46\% memiliki pendidikan terakhir S1. Berdasarkan riwayat kanker pada keluarga, sebagian besar karyawati $(95,5 \%)$ yang tidak memiliki riwayat kanker dalam keluarga.

Tabel 1 Karakteristik karyawati dan pemanfaatan Layanan Kesehatan Perempuan (MAWAS)

\begin{tabular}{llc}
\hline Karakteristik Karyawati & n & \% \\
\hline Kelompok Umur & & \\
Dewasa Muda (18-25 tahun) & 23 & 20,72 \\
Dewasa Penuh (26-65 tahun) & 88 & 79,28 \\
Mean \pm SD (34,5 $\pm 10,55)$ & & \\
Min-Max (22-57) & &
\end{tabular}




\section{Status Perkawinan}

Kawin $\quad 77$

69,37

Belum Kawin

26,13

Janda

29

Status Kepegawaian

Aparatur Sipil Negara (ASN)

Tenaga Kegiatan (Kontrak)

\section{Lama bekerja}

1 tahun

$>1$ tahun

Mean \pm SD $(6,19 \pm 6,22)$

Min-Max (1-32)

\section{Pendidikan Terakhir}

D III

36

32,43

S1

66

59,46

S2

9

Riwayat kanker pada keluarga

Ada

Tabel 2 menunjukkan dari 15 pernyataan mengenai pengetahuan yang meliputi pemanfaatan dan prosedur pemeriksaan Layanan Kesehatan Perempuan (MAWAS) karyawati yang menjawab dengan tepat pada beberapa pernyataan dalam kuesioner memiliki presentase kurang dari 50\% karyawati. Hal ini dapat mengindikasikan bahwa terdapat pengetahuan yang meliputi pemanfaatan dan prosedur pemeriksaan Layanan Kesehatan Perempuan (MAWAS) yang masih kurang diketahui oleh karyawati. Pernyataan paling banyak dijawab tidak tepat adalah mengenai frekuensi pemanfaatan layanan. Sebanyak 61,26\% karyawati mengira bahwa layanan MAWAS tidak dapat dimanfaatkan 1 kali dalam setahun. Hal berikutnya yang kurang diketahui karyawati adalah prosedur pemeriksaan layanan. Sebanyak $54,95 \%$ karyawati mengira hasil pemeriksaan dapat diambil langsung sesaat setelah hasil pemeriksaan dilakukan. Hal lainnya tentang prosedur layanan juga kurang diketahui karyawati. Sebanyak 51,35\% mengira pemeriksaan di Layanan Kesehatan Perempuan (MAWAS) dikenakan biaya

Tabel 2 Distribusi jawaban karyawati (MAWAS) ( $=111$ orang) 


\begin{tabular}{|c|c|c|c|c|c|}
\hline & \multirow[t]{2}{*}{ Pernyataan } & \multicolumn{2}{|c|}{ Benar } & \multicolumn{2}{|c|}{ Salah } \\
\hline & & $\mathbf{n}$ & $\%$ & $\mathbf{n}$ & $\%$ \\
\hline 1 & $\begin{array}{l}\text { Layanan MAWAS merupakan layanan } \\
\text { deteksi dini kanker payudara yang berada di } \\
\text { Kabupaten Badung }\end{array}$ & 110 & 99,10 & 1 & 0,90 \\
\hline 2 & $\begin{array}{l}\text { Layanan MAWAS hanya dapat dimanfaatkan } \\
\text { oleh masyarakat yang memiliki KTP Badung }\end{array}$ & 79 & 71,17 & 32 & 28,83 \\
\hline 3 & $\begin{array}{l}\text { Layanan MAWAS tidak dapat dimanfaatkan } \\
\text { oleh karyawati di lingkungan Pemerintahan } \\
\text { Kabupaten Badung }\end{array}$ & 88 & 79,28 & 23 & 20,72 \\
\hline 4 & $\begin{array}{l}\text { Karyawati Dinas Kesehatan Kabupaten } \\
\text { Badung dari segala usia dapat memanfaatkan } \\
\text { Layanan MAWAS }\end{array}$ & 66 & 59,46 & 45 & 40,54 \\
\hline 5 & $\begin{array}{l}\text { Layanan MAWAS dapat dimanfaatkan oleh } \\
\text { karyawati Dinas Kesehatan Kabupaten } \\
\text { Badung sebanyak } 1 \text { kali dalam setahun }\end{array}$ & 43 & 38,74 & 68 & 61,26 \\
\hline 6 & $\begin{array}{l}\text { Layanan MAWAS dapat dimanfaatkan oleh } \\
\text { karyawati Dinas Kesehatan Kabupaten } \\
\text { Badung setiap hari Senin sampai dengan } \\
\text { Sabtu pada jam kerja }\end{array}$ & 86 & 77,48 & 25 & 22,52 \\
\hline 7 & $\begin{array}{l}\text { Karyawati Dinas Kesehatan Kabupaten } \\
\text { Badung yang ingin memanfaatkan layanan } \\
\text { MAWAS dapat melakukan pendaftaran pada } \\
\text { petugas di Sekretariat MAWAS Dinas } \\
\text { Kesehatan Kabupaten Badung }\end{array}$ & 98 & 88,29 & 13 & 11,71 \\
\hline 8 & $\begin{array}{l}\text { Persyaratan administrasi pendaftaran untuk } \\
\text { karyawati atau pegawai Kabupaten Badung } \\
\text { jika melakukan pemeriksaan di Layanan } \\
\text { MAWAS adalah menyerahkan foto copy } \\
\text { KTP atau foto copy Kartu Pegawai }\end{array}$ & 68 & 61,26 & 43 & 38,74 \\
\hline 9 & $\begin{array}{l}\text { Bagi karyawati Dinas Kesehatan Kabupaten } \\
\text { Badung yang melakukan pemeriksaan di } \\
\text { Layanan MAWAS dikenakan biaya }\end{array}$ & 54 & 48,65 & 57 & 51,35 \\
\hline 10 & $\begin{array}{l}\text { Karyawati Dinas Kesehatan Kabupaten } \\
\text { Badung yang sedang hamil dan menyusui } \\
\text { dapat melakukan pemeriksaan di Layanan } \\
\text { MAWAS }\end{array}$ & 65 & 58,86 & 46 & 41,44 \\
\hline 11 & $\begin{array}{l}\text { Jika karyawati Dinas Kesehatan Kabupaten } \\
\text { Badung sedang dalam keadaan menstruasi, }\end{array}$ & 68 & 61,26 & 43 & 38,74 \\
\hline
\end{tabular}


Vol. 7 No. 2 : 81 - 94

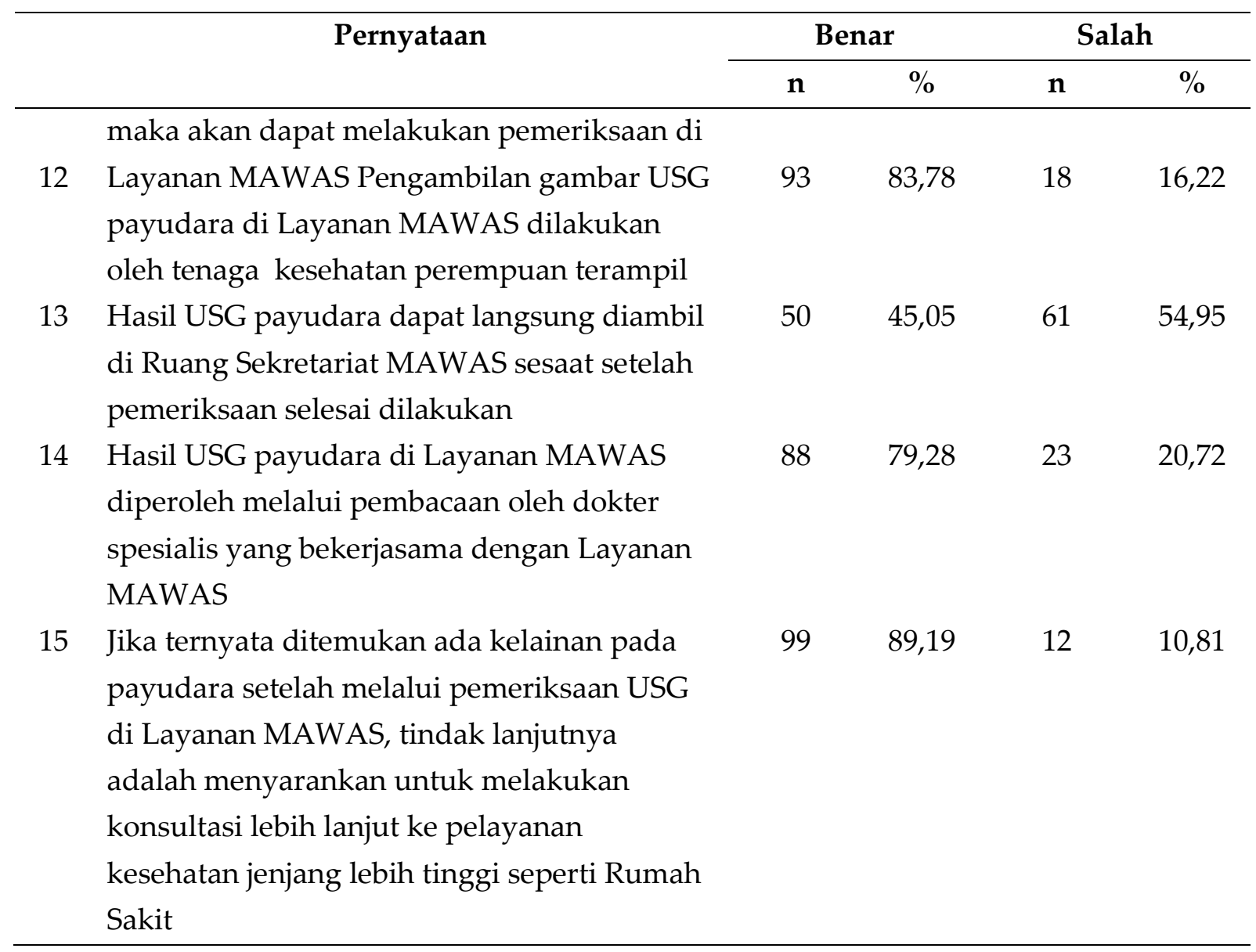

Berdasarkan Tabel 3, nilai rata-rata pengetahuan karyawati adalah 10,5 (SD = 3,07), nilai median adalah 11 dengan nilai terendah adalah 5 dan nilai tertinggi 15 . Sebanyak 53,15\% karyawati memiliki pengetahuan kurang tentang layanan dan merupakan frekuensi terbanyak, sedangkan sisanya sebanyak 44,95\% memiliki pengetahuan baik tentang layanan. Berdasarkan persepsi risiko, sebanyak $71,17 \%$ karyawati memiliki persepsi kurang berisiko terhadap kanker payudara dan merupakan frekuensi terbanyak sedangkan sebanyak 28,83\% karyawati memiliki persepsi cukup dan sangat berisiko terhadap kanker payudara.

Tabel 3 Gambaran pengetahuan tentang layanan, persepsi risiko kanker payudara dengan pemanfaatan Layanan Kesehatan Perempuan (MAWAS)

\begin{tabular}{lll}
\hline Karakteristik & $\mathbf{n}$ & \% \\
\hline Kategori Pengetahuan & & \\
$\quad$ Kurang & & \\
Baik & 60 & 54,05 \\
$\quad$ Mean \pm SD $(10,5 \pm 3,07)$ & 51 & 45,95 \\
$\quad$ Median 11 & & \\
Min-Max (5-15) & & \\
Persepsi Risiko & & \\
\hline
\end{tabular}




\begin{tabular}{ccc}
\hline Karakteristik & $\mathbf{n}$ & $\mathbf{\%}$ \\
\hline Kurang berisiko & 79 & 71,17 \\
Cukup dan sangat berisiko & 32 & 28,83 \\
\hline
\end{tabular}

Tabel 4 menunjukkan karyawati yang pernah memanfaatkan layanan lebih banyak pada karyawati dengan kelompok umur dewasa penuh (63,64\%) dibandingkan pada dewasa muda dan perbedaan tersebut bermakna secara statistik $(p=0,034)$. Apabila dilihat dari karakteristik status perkawinan, proporsi karyawati yang pernah memanfaatkan layanan lebih banyak pada karyawati dengan status kawin (61,04\%) dibandingkan dengan karyawati dengan status belum kawin dan janda namun perbedaan tersebut tidak bermakna secara statistik ( $p=0,425)$. Pada karakteristik status kepegawaian, proporsi karyawati yang pernah memanfaatkan layanan lebih banyak pada karyawati dengan status ASN (73,47\%) dibandingkan karyawati dengan status kepegawaian kontrak dan perbedaan tersebut bermakna secara statistik $(p=0,005)$.

Jika ditinjau dari karakteristik lama bekerja, proporsi karyawati yang pernah memanfaatkan layanan lebih banyak pada karyawati yang bekerja selama 1 tahun $(66,67 \%)$ dibandingkan dengan karyawati yang bekerja $>1$ tahun namun perbedaan tersebut tidak bermakna secara statistik ( $p$ $=1,000)$. Pada karakteristik pendidikan terakhir, proporsi karyawati yang pernah memanfaatkan layanan lebih banyak pada responden dengan pendidikan diploma $(61,11 \%)$ dibandingkan karyawati dengan pendidikan sarjana namun perbedaan tersebut tidak bermakna secara statistik ( $p$ $=0,705)$. Pada karakteristik riwayat kanker pada keluarga, proporsi karyawati yang pernah memanfaatkan layanan lebih banyak pada karyawati yang tidak memiliki riwayat kanker pada keluarga (59,43\%) dibandingkan karyawati yang memiliki riwayat kanker pada keluarga namun perbedaan tersebut tidak bermakna secara statistik.

Berdasarkan pengetahuan dapat dilihat bahwa proporsi karyawati yang belum pernah memanfaatkan layanan MAWAS dengan pengetahuan kurang tentang layanan lebih banyak (65\%) dibandingkan dengan responden dengan pengetahuan baik dan perbedaan tersebut bermakna secara statistik ( $p<0,001)$. Karyawati yang pernah memanfaatkan layanan MAWAS yang memiliki persepsi cukup dan sangat berisiko terhadap kanker payudara lebih banyak (62,50\%) dibandingkan dengan karyawati yang memiliki persepi cukup berisiko terhadap kanker payudara namun perbedaan tersebut tidak bermakna secara statistik yaitu $\mathrm{p}=0,592$. 
Tabel 4 Hasil analisis bivariat karakteristik sosio-demografi, pengetahuan tentang layanan, persepsi risiko kanker payudara dengan pemanfaatan Layanan Kesehatan Perempuan (MAWAS)

\begin{tabular}{|c|c|c|c|}
\hline \multirow{2}{*}{ Karakteristik } & \multicolumn{2}{|c|}{ Pemanfaatan Layanan } & \multirow{2}{*}{ p value } \\
\hline & $\begin{array}{c}\text { Pernah } \\
\text { n (\%) }\end{array}$ & $\begin{array}{c}\text { Belum Pernah } \\
\text { n (\%) }\end{array}$ & \\
\hline \multicolumn{4}{|l|}{ Kelompok Umur } \\
\hline Dewasa Muda (18-25 tahun) & $9(39,13)$ & $14(60,87)$ & 0,034 \\
\hline Dewasa Penuh (26-65 tahun & $56(63,64)$ & $32(36,36)$ & \\
\hline \multicolumn{4}{|l|}{ Status Perkawinan } \\
\hline Kawin & $47(61,04)$ & $47(61,04)$ & 0,425 \\
\hline Belum Kawin dan Janda & $18(52,94)$ & $18(52,94)$ & \\
\hline \multicolumn{4}{|l|}{ Status Kepegawaian } \\
\hline ASN & $36(73,47)$ & $13(26,53)$ & 0,005 \\
\hline Tenaga Kegiatan (Kontrak) & $29(46,77)$ & $33(53,23)$ & \\
\hline \multicolumn{4}{|l|}{ Lama Bekerja } \\
\hline 1 tahun & $4(66,67)$ & $2(33,33)$ & 1,000 \\
\hline$>1$ tahun & $61(58,10)$ & $44(41,90)$ & \\
\hline \multicolumn{4}{|l|}{ Pendidikan Terakhir } \\
\hline Diploma & $22(61,11)$ & $14(38,89)$ & 0,705 \\
\hline Sarjana & $43(57,33)$ & $32(42,67)$ & \\
\hline \multicolumn{4}{|l|}{ Riwayat Kanker } \\
\hline Ada & $2(40)$ & $3(60)$ & 0,647 \\
\hline Tidak Ada & $63(59,43)$ & $43(40,57)$ & \\
\hline \multicolumn{4}{|l|}{ Kategori Pengetahuan } \\
\hline Kurang & $21(35,00)$ & $39(65,00)$ & $<0,001$ \\
\hline Baik & $44(86,27)$ & $7(13,73)$ & \\
\hline \multicolumn{4}{|l|}{ Persepsi Risiko } \\
\hline Kurang Berisiko & $45(56,96)$ & $34(43,04)$ & 0,592 \\
\hline Cukup dan Sangat & $20(62,50)$ & $12(37,50)$ & \\
\hline Berisiko & & & \\
\hline
\end{tabular}

\section{DISKUSI}

Pemanfaatan Layanan Kesehatan Perempuan (MAWAS)

Hasil penelitian ini menunjukkan bahwa lebih dari 40\% karyawati Dinas Kesehatan Kabupaten Badung belum pernah memanfaatkan Layanan Kesehatan
Perempuan (MAWAS) meskipun layanan tersebut sudah berjalan selama kurang lebih 4 tahun. Hal tersebut dapat mengindikasikan bahwa pemanfaatan Layanan Kesehatan Perempuan (MAWAS) masih belum optimal. Belum adanya 
sosialisasi yang memadai dengan meggunakan media brosur yang berisikan tentang layanan tersebut kepada karyawati dapat menjadi penyebab kurangnya jangkauan informasi yang dimiliki oleh karyawati sehingga memberikan pengaruh terhadap pemanfaatan layanan. Selain itu, kurangnya informasi tersebut juga diindikasikan menyebabkan kurangnya pengetahuan yang dimiliki oleh karyawati terkait pemanfaatan dan prosedur Layanan Kesehatan Perempuan (MAWAS). Dapat dilihat dari hasil jawaban karyawati pada 15 pernyataan yang diberikan masih terdapat jawaban yang dijawab kurang tepat kurang dari $50 \%$ oleh karyawati. Jawaban paling banyak dijawab tidak tepat adalah mengenai frekuensi pemanfaatan layanan. Sebanyak 61,26\% karyawati mengira bahwa layanan MAWAS tidak dapat dimanfaatkan 1 kali dalam setahun. Kurangnya pengetahuan karyawati akan hal itu dapat membuat karyawati tidak memanfaatkan layanan. Hal berikutnya yang kurang diketahui karyawati adalah prosedur pemeriksaan layanan. Sebanyak $54,95 \%$ karyawati mengira hasil pemeriksaan dapat diambil langsung sesaat setelah hasil pemeriksaan dilakukan. Hal lainnya tentang prosedur layanan juga kurang diketahui karyawati Sebanyak 51,35\% mengira pemeriksaan di Layanan Kesehatan Perempuan (MAWAS) dikenakan biaya. Teori yang dikemukakan oleh Budiman \& Riyanto (2013) menyebutkan bahwa informasi/media massa merupakan salah satu faktor yang dapat mempengaruhi pengetahuan seseorang. Sehingga kurangnya pengetahuan karyawati akan pemanfaatan dan prosedur pemeriksaan layanan dapat mengindikasikan karyawati tidak memanfaatkan layanan secara optimal.

Penelitian ini sejalan dengan penelitian yang dilakukan oleh Wijaya (2016) mengenai perilaku deteksi dini kanker payudara. Pada penelitian tersebut ditemukan cukup tinggi proporsi wanita yang tidak melakukan SADARI sebesar $81,67 \%$, proporsi wanita yang tidak melakukan SADANIS sebesar 91,67\% serta proporsi wanita yang tidak melakukan mammografi sebesar 98,3\%. ${ }^{6}$ Penelitian lain yang dilakukan Harahap (2011) pada karyawati Dinas Pendidikan juga menunjukkan hasil yang sama bahwa perilaku karyawati mengenai SADARI termasuk dalam kategori kurang $(68,10 \%)$. Penelitian-penelitian tersebut dapat mengindikasikan bahwa perilaku deteksi dini kanker payudara masih rendah. Namun jika dibandingkan secara proporsi, pada penelitian ini masih lebih tinggi dikarenakan respondennya merupakan karyawati Dinas Kesehatan Kabupaten Badung yang sebagian besar merupakan tenaga kesehatan. Namun jika dibandingkan dengan rekomendasi tersebut, perilaku deteksi dini oleh Karyawati Dinas Kesehatan Kabupaten Badung dapat dikatakan masih kurang karena terdapat lebih dari $41,44 \%$ yang belum melakukan deteksi dini kanker payudara.

\section{Gambaran karakteristik sosio-demografi} dengan pemanfaatan Layanan Kesehatan Perempuan (MAWAS)

Hasil penelitian ini menunjukkan bahwa karakteristik umur berhubungan dengan pemanfaatan Layanan Kesehatan Perempuan (MAWAS). Proporsi karyawati Dinas Kesehatan Kabupaten Badung yang 
pernah memanfaatkan layanan cenderung lebih tinggi pada kelompok umur dewasa penuh $(63,64 \%)$ dibandingkan dengan kelompok dewasa muda. Penelitian ini menunjukkan semakin tinggi umur karyawati maka akan lebih cenderung untuk memanfaatkan layanan deteksi dini kanker payudara dikarenakan umur yang semakin tinggi merupakan salah satu faktor risiko terjadinya kanker payudara sehingga akan meningkatkan perilaku pemanfaatan layanan deteksi dini kanker payudara. Selain itu semakin tua umur karyawati maka akan memiliki ketahanan fisik yang semakin menurun sehingga lebih rentan terpapar suatu penyakit dan apabila sakit, aktivitas karyawati dapat terganggu sehingga dapat menghambat aktivitas karyawati tersebut. Menurut Depkes (2014) menyebutkan adapun faktor risiko terjadinya kanker payudara salah satunya yaitu umur. Komite Nasional Penanganan Kanker (2015) juga menyebutkan bahwa kejadian kanker payudara meningkat dengan bertambahnya umur. Hal tersebut didukung oleh penelitan Sihombing dan Saparadin (2014) juga menyebutkan bahwa wanita dengan umur $\geq 40$ tahun berisiko 13,34 kali untuk terkena kanker payudara dibandingkan dengan kelompok umur $<40$ tahun. Penelitian lain oleh Pratama (2017) juga menyebutkan proporsi WUS yang melakukan skrining kanker payudara lebih banyak pada usia tua dibandingkan dengan usia muda.

Selain itu, karakteristik status kepegawaian juga memiliki hubungan dengan pemanfaatan Layanan Kesehatan Perempuan (MAWAS). Proporsi karyawati yang pernah memanfaatkan layanan MAWAS lebih tinggi dibandingan dengan karyawati dengan status ASN (73,47\%) dibandingkan dengan karyawati dengan status kontrak. Selama ini terbatas literatur yang membahas hubungan antara karakteristik status kepegawaian dengan pemanfaatan layanan deteksi dini kanker payudara. Peneliti beranggapan hal tersebut dapat terjadi dikarenakan ASN merupakan karyawan tetap yang tidak akan mengalami risiko pemutusan pekerjaan, sehingga merasa memiliki hak yang lebih tinggi untuk memanfaatkan layanan MAWAS dibandingkan dengan karyawati dengan status kontrak. Namun hal tersebut belum diketahui pasti oleh peneliti mengingat masih terbatasnya teori mengenai hal tersebut.

\section{Gambaran pengetahuan tentang layanan dengan pemanfaatan Layanan Kesehatan Perempuan (MAWAS)}

Hasil penelitian ini menujukkan bahwa sebagian besar karyawati memiliki pengetahuan kurang tentang layanan. Hal ini terkait dengan masih terdapat aspek pemanfaatan dan prosedur pemeriksaan layanan yang belum diketahui responden dapat dilihat pada 15 pernyataan yang diberikan pada kuesioner masih terdapat jawaban yang dijawab kurang tepat lebih dari 50\%. Ketidaktahuan karyawati dalam beberapa aspek tentang pemanfaatan dan prosedur pemeriksaan tersebut dapat menyebabkan karyawati untuk tidak memanfaatkan Layanan Kesehatan Perempuan (MAWAS) secara optimal. Notoatmodjo (2011) mengatakan bahwa semakin tinggi pengetahuan seseorang maka semakin tinggi pula kemampuan 
individu tersebut di dalam melakukan penilaian terhadap suatu materi atau objek Penilaian tersebut inilah yang akan menjadi landasan seseorang untuk bertindak atau berperilaku. Pengetahuan dapat menjadikan seseorang memiliki kesadaran sehingga seseorang akan berperilaku sesuai dengan pengetahuan yang dimiliki. Sehingga jika pengetahuan tentang Layanan Kesehatan Perempuan (MAWAS) oleh karyawati adalah kurang maka karyawati tersebut tidak memanfaatkan layanan.

Hasil penelitian ini juga didukung oleh penelitian Purba (2018) yang menunjukkan lebih dari 30\% WUS memiliki pengetahuan kurang tentang deteksi dini kanker dengan metode SADARI. Penelitian lain menunjukkan sebesar $34,40 \%$ WUS memiliki pengetahuan yang kurang tentang perilaku deteksi dini kanker payudara (Ekanita and Khosidah, 2011). Penelitan-penelitian tersebut menunjukkan bahwa pengetahuan tentang deteksi dini kanker payudara maupun tentang layanan deteksi dini kanker payudara masih kurang. Namun terdapat perbedaan proporsi hasil penelitian ini dengan penelitian terkait dikarenakan terdapat perbedaan pada pengkategorian pengetahuan sehingga dapat menghasilkan perbedaan proporsi pada penelitian peniliti walaupun karyawati Dinas Kesehatan Kabupaten Badung sebagian besar merupakan tenaga kesehatan.

Gambaran persepi risiko kanker payudara dengan pemanfaatan Layanan Kesehatan Perempuan (MAWAS)

Penelitian ini menunjukkan bahwa lebih dari 70\% karyawati Dinas Kesehatan
Kabupaten Badung memiliki persepsi kurang berisiko terhadap kanker payudara. Karyawati dengan persepsi kurang berisiko terhadap kanker payudara cenderung lebih banyak untuk tidak memanfaatkan layanan. Hal tersebut dapat terjadi dikarenakan jika karyawati tersebut merasa bahwa dirinya tidak rentan akan menderita kanker payudara sehingga karyawati merasa tidak perlu untuk melakukan deteksi dini kanker payudara. Notoatmodjo (2010) menyebutkan bahwa semakin tinggi atau positif persepsi seseorang terhadap risiko penyakut maka akan cenderung untuk memanfaatkan layanan kesehatan. ${ }^{15}$ Begitupula pada penelitian ini, jika semakin kurang risiko terhadap kanker payudara yang dirasakan oleh karyawati maka akan diikuti oleh perilaku untuk tidak melakukan pemeriksaan deteksi dini kanker payudara. Penelitian ini didukung oleh penelitian Kusumaningrum \& Sari (2018) yang menyebutkan bahwa sebesar $58 \%$ remaja memiliki persepsi risiko kurang terhadap kanker payudara dan sebesar $42 \%$ remaja memiliki persepsi risiko tinggi terhadapa kanker payudara. Penelitian lain juga menyebutkan hasil yang sama, proporsi remaja putri yang memiliki persepsi kurang beresiko terhadap kanker payudara dan SADARI lebih banyak (50,8\%) dibandingkan dengan persepsi risiko tinggi (49,2\%). (Apriliyana et al., 2017)

Hubungan Pengetahuan tentang layanan dengan pemanfaatan Layanan Kesehatan Perempuan (MAWAS)

Hasil penelitian menunjukkan terdapat hubungan antara pengetahuan tentang layanan dengan pemanfaatan 
Layanan Kesehatan Perempuan (MAWAS). Pengetahuan yang dimiliki oleh karyawati akan berhubungan dengan perilaku karyawati dalam memanfaatkan Layanan Kesehatan Perempuan (MAWAS). Semakin baik pengetahuan karyawati tentang pemanfaatan dan prosedur layanan deteksi dini kanker payudara, maka semakin baik pula karyawati tersebut untuk memanfaatkan layanan. Begitupula sebaliknya, jika pengetahuan tentang layanan kurang maka akan memiliki dampak untuk tidak memanfaatkan layanan deteksi dini kanker payudara yang ada. Green (1980) dalam Notoatmodjo (2010) menyebutkan bahwa salah satu faktor predisposisi yang mempengaruhi seseorang dalam pemanfaatan layanan kesehatan adalah pengetahuan. Sehingga hasil penelitian ini sejalan dengan teori tersebut.

Penelitian ini juga didukung oleh penelitian Ekanita \& Khosidah (2011) yang menyebutkan proporsi WUS yang tidak melakukan SADARI lebih banyak pada yang memiliki pengetahuan kurang (90,6\%) dibandingkan dengan WUS dengan pengetahuan baik serta terdapat hubungan bermakna antara pengetahuan dengan perilaku SADARI $(p=0,001)$. Hasil yang sama menunjukkan proporsi WUS yang tidak melakukan upaya deteksi dini SADARI dengan pengetahuan kurang akan SADARI (33,3\%) lebih tinggi dibandingkan dengan pengetahuan baik $(3,2 \%)$ dan perbedaan tersebut memiliki hubungan ( $p=0,04)$ (Purba, 2018).

\footnotetext{
Hubungan persepi risiko kanker payudara dengan pemanfaatan Layanan Kesehatan Perempuan (MAWAS)
}

Penelitian ini menunjukkan tidak terdapat hubungan antara persepsi risiko kanker payudara dengan pemanfaatan layanan MAWAS. Persepsi risiko yang dirasakan oleh karyawati baik itu persepsi kurang berisiko, cukup berisiko dan sangat berisiko tidak mempengaruhi perilaku karyawati dalam memanfaatkan Layanan Kesehatan Perempuan (MAWAS). Namun berdasarkan teori Green dalam Notoatmodjo (2010) mengatakan bahwa persepsi merupakan faktor predisposisi seseorang dalam memanfaatkan layanan kesehatan. Semakin tinggi atau positif persepsi seseorang maka akan cenderung untuk memanfaatkan layanan kesehatan. Sehingga hasil penelitian ini bertolak belakang dengan teori tersebut yang dapat terjadi dikarenakan ada faktor lain yang berhubungan dengan perilaku pemanfataan layanan deteksi dini kanker payudara yang belum diketahui oleh peneliti.

Namun penelitian ini didukung oleh penelitian yang dilakukan oleh Apriliyana, dkk (2017) menunjukkan bahwa remaja putri yang tidak melakukan deteksi dini kanker payudara lebih banyak pada mereka yang memiliki persepsi kurang berisiko terhadap kanker payudara (51,5\%) dibandingkan dengan yang memiliki persepsi sangat berisiko. Hasil uji chi square menunjukkan tidak ada hubungan antara persepsi risiko kanker payudara dengan perilaku deteksi dini kanker payudara $(\mathrm{p}=$ 0,256).

Hasil yang berbeda terlihat pada penelitian Marsha (2014) yang menggunakan teori berbeda yaitu teori Health Belief Model (HBM) untuk megetahui 
hubungan persepsi risiko terhadap pelaksanaan deteksi dini kanker payudara dengan metode SADARI. Hasil penelitian menunjukkan bahwa terdapat hubungan antara persepsi risiko dengan pelaksanaan deteksi dini kanker payudara dengan metode SADARI. Perbedaan hasil penelitian ini diperkirakan dapat terjadi dikarenakan ada faktor lain yang berhubungan dengan perilaku pemanfataan layanan deteksi dini kanker payudara yang belum diketahui oleh peneliti.

\section{SIMPULAN}

Hasil penelitian menunjukkan $58,56 \%$ responden pernah memanfaatkan layanan MAWAS. Sebagian responden (54,05\%) memiliki pengetahuan kurang tentang layanan dan sebagian responden (71,17\%) memiliki persepsi kurang berisiko terhadap kanker payudara. Terdapat hubungan antara karakteristik umur, status kepegawaian dan pengetahuan tentang layanan dengan pemanfaatan layanan Kesehatan Perempuan (MAWAS).

\section{SARAN}

Sosialisasi dapat dilakukan dengan menggunakan media cetak seperti brosur yang berisikan informasi tentang pemanfaatan layanan, prosedur layanan yang meliputi persyaratan pemeriksaan dan frekuensi pemanfaatan guna mempermudah penyampaian informasi tentang layanan sehingga karyawati mengetahui lebih banyak tentang layanan. Sosialisasi tersebut diharapkan dapat meningkatkan pengetahuan, minat dan keikutsertaan Karyawati Dinas Kesehatan Kabupaten Badung dalam memanfaatkan layanan deteksi dini kanker payudara yang sudah ada.

\section{DAFTAR PUSTAKA}

Alkhasawneh, I. M., Akhu-Zaheya, L. M. and Suleiman, S. M. (2009) 'Jordanian nurses' knowledge and practice of breast self-examination', Journal of Advanced Nursing. John Wiley \& Sons, Ltd (10.1111), 65(2), pp. 412-416. doi: 10.1111/j.1365-2648.2008.04891.x.

Apriliyana, D. et al. (2017) 'Hubungan Persepsi, Paparan Media Informasi Dan Dukungan Orang Tua Dengan Praktik Pemeriksaan Payudara Sendiri (SADARI) Pada Remaja Putri Di SMA Negeri 3 Semarang Tahun 2017', 5, pp. 207-214. Available at: https://ejournal3.undip.ac.id/index.ph $\mathrm{p} / \mathrm{jkm} /$ article/viewFile/18347/17426.

Budiman and Riyanto, A. (2013) Kapita Selekta Kuisioner Pengetahuan Dan Sikap Dalam Penelitian Kesehatan. Jakarta: Salemba Medika.

Depkes RI (2014) Buku Saku Pencegahan Kanker Leher Rahim dan Kanker Payudara. Jakarta: Kementerian Kesehatan RI.

Ekanita, P. and Khosidah, A. (2011) 'Hubungan Antara Pengetauan dan Sikap WUS Terhadap Perilaku Pemeriksaan Payudara Sendiri (SADARI)', Jurnal Ilmiah Kebidanan, 0281641655(274), pp. 167-177. doi: 10.1073/pnas.1412481111.

Harahap, N. H. (2011) 'Perilaku Karyawati di Kantor Dinas Pendidikan Sumatera Utara mengenai Metode SADARI Sebagai Deteksi Dini Kanker Payudara'. Available at: http://repository.usu.ac.id/handle/123 456789/21619 (Accessed: 23 June 2019).

Kementerian Kesehatan RI (2015) Panduan Program Nasional Gerakan Pencegahan dan Deteksi Dini Kanker Leher Rahim. Jakarta. 
Komite Nasional Penanganan Kanker (2015) Panduan Penatalaksanaan Kanker Payudara, Kementerian Kesehatan Republik Indonesia. Komite Penanggulangan Kanker Nasional. Available at: https://books.google.co.id/books?id=5 6n7wtKMUPcC\&pg=PA23\&dq=pemer iksaan+payudara+sendiri\&hl=id\&sa= $\mathrm{X} \&$ redir_esc $=\mathrm{y} \# \mathrm{v}=$ onepage \& $\mathrm{q}=$ pemeri ksaan payudara sendiri\&f=false.

Kusumaningrum, T. A. and Sari, N. K. (2018) 'Aplikasi Health Belief Model Pada Perilaku Mahasiswi Kesehatan Masyarakat Dalam Pmeriksaan Payudara Sendiri (SADARI)', 11(2), pp. 1-11.

Marsha, Z. (2014) ‘Hubungan Health Belief Model Dengan Pelaksanaan SADARI Deteksi Dini Kanker Payudara Di Keluarahan Purus Wilayah Kerja Puskesmas Padang Pasir Kota Padang'. Available at: http://scholar.unand.ac.id/9790/ (Accessed: 25 July 2019).

Notoatmodjo, S. (2010) Ilmu dan Perilaku Kesehatan. Jakarta: Rineka Cipta.

Notoatmodjo, S. (2011) Kesehatan Masyarakat. Jakarta: Rineka Cipta.

Pratama, S. T. (2017) 'Faktor yang Mempengaruhi Wanita Usia Subur (WUS) Melakukan Skrining Kanker Payudara Pada Layanan Mangupura Woman Service (Mawas) di
Kecamatan Abiansemal, Kabupaten Badung'.

Purba, A. S. (2018) 'Hubungan Pengetahuan Dan Sikap Tentang Sadari Dengan Tindakan WUS Melakukan Pemeriksaan SADARI Di Puskesmas Sunggal Tahun 2018', 3(1), pp. 1-12. Available at: e-journal.sarimutiara.ac.id/index.php/6/article/dow nload/456/428.

Sihombing, M. and Sapardin, A. N. (2011) 'Faktor Risiko Tumor Payudara Pada Perempuan Umur 25-65 Tahun Di Lima Kelurahan Kecamatan Bogor Tengah'.

WHO (2018a) Breast cancer. World Health Organization. Available at: https:/www.who.int/cancer/preventio $\mathrm{n} /$ diagnosis-screening/breastcancer/en/ (Accessed: 10 February 2019).

WHO (2018b) Fact Sheet On Breast Cancer. Available at: https://www.iarc.fr/featurednews/breast-cancer-awareness-month2018/ (Accessed: 10 February 2019).

Wijaya, I. L. (2016) 'Gambaran Skrining Deteksi Dini Kanker Payudara Pada Wanita Usia Dewasa Di Wilayah Kerja Puskes,as Pandak I Bantul Yogyakarta'. Available at: http://repository.unjaya.ac.id/659/1/Int an Laga Wijaya_2212172_nonfull resize.pdf. 